\title{
PENGEMBANGAN BAHAN AJAR TEKS EKSPOSISI PADA SISWA KELAS X SMA
}

\author{
Nurhesti Rahmadani, Ade Maruli Tua Dongoran, Rosmawati Harahap \\ Universitas Muslim Nusantara Al Washliyah Medan \\ Nurhestirahmadani1@gmail.com \\ adeofficedongoran@yahoo.com
}

\begin{abstract}
ABSTRAK: Permasalahan dalam penelitian ini adalah proses pengembangan bahan ajar teks eksposisi, efektivitas hasil pengembangan bahan ajar teks eksposisi dan kelayakan hasil validasi ahli pada siswa kelas X SMA Negeri 14 Medan Tahun Pembelajaran 2018-2019. Tujuan penelitian ini adalah untuk mendeskripsikan proses pengembangan bahan ajar teks eksposisi, efektivitas penggunaan bahan ajar teks eksposisi dan kelayakan hasil validasi ahli pada siswa kelas X SMA Negeri 14 Medan Tahun Pembelajaran 2018-2019. Penelitian ini menggunakan metode R\&D. Subjek penelitian ini adalah siswa kelas X SMA Negeri 14 Medan. Penelitian ini menggunakan instrumen nontes dan instrumen tes. Hasil penelitian ini menunjukkan bahwa pengembangan bahan ajar menulis teks eksposisi pada siswa kelas $\mathrm{X}$ SMA Negeri 14 Medan Tahun pembelajaran 2018-2019, dimana sebelum proses pengembangan bahan ajar menulis teks eksposisi berada pada kategori cukup dan kemudian meningkat menjadi baik setelah proses pengembangan bahan ajar menulis teks eksposisi di kelas X SMA Negeri 14 Medan Tahun Pembelajaran 2018-2019.
\end{abstract}

KATA KUNCI: pengembangan, bahan ajar, teks eksposisi, efektivitas, validasi.

\begin{abstract}
The problem with this study is the development of the exposed text tex, the effectiveness of the development of the exposed text, and the worthiness of the validation result of expert validation on the country's 14-outdoor x high scholl student 2018-2019 learning year. The purpose of this study is to describe the process of developing the exposed text material, the effectiveness of use of the exposed text text, and the worthiness of validation result from experts in the country's 14 th grade $x$ high school learning year 2018-2019. The study USES r\&d methods. This research subject is a 14-year-old country $x$ high school student. The study USES nontes and test instruments. The result of this study shows that the development of the teaching material writes the exposed text of the country's 14 high- school x student of 2018-2019 fields of learning, in which before the process of developing the teaching material writes the exposed text is in sufficient category and then rises to be good after the process of developing the teaching material writes the exposed text of the country's 14th field x class of 2018-2019 learning year.

KEYWORDS: Development, ajar, exposed text, efectivitas, validation.
\end{abstract}

\section{PENDAHULUAN}

Dalam proses pembelajaran di kelas, bahan ajar menjadi salah satu komponen pendukung untuk mencapai tujuan pembelajaran. Bahan ajar merupakan komponen isi pesan yang harus disampaikan kepada siswa. Tanpa bahan ajar, maka proses pembelajaran tidak memperoleh hasil yang baik, bahkan tidak akan menghasilkan apa-apa. Bahan ajar sendiri mempunyai pengertian sebagai segala bentuk bahan (baik informasi, alat, maupun teks). Bahan ajar disusun secara sistematis yang menampilkan sosok utuh dari kompetensi yang akan dikuasai peserta didik dan digunakan dalam proses pembelajaran. Bahan ajar sesuai tujuan perencanaan dan penelaahan, penerapan pembelajaran, misalnya buku pelajaran, modul, handout, LKS, model, audio, dan sebagainya.

Materi pelajaran bahasa Indonesia dalam kurikulum 2013 berbasis teks. Tujuan pembelajaran bahasa Indonesia berbasis teks memang baik. Namun di lapangan, peserta didik menjadi jenuh karena setiap kali harus berhadapan dengan teks. Disamping itu, materi sastra yang sangat bermanfaat untuk mengembangkan karakter dan budi pekerti 
pesera didik banyak dihilangkan. Pembelajaran bahasa Indonesia adalah bagian dari Kurikulum 2013 yang menekankan pentingnya keseimbangan kompetensi sikap, pengetahuan dan keterampilan yang berbasis teks. Dengan pembelajaran berbasis teks ini akan membawa dan melatih mental peserta didik sesuai dengan perkembangannya. Selain itu, pembelajaran akan selalu berfokus pada teks-teks. Peserta didik dituntut untuk mengamati, menanya, menalar, mencoba, serta mengomunikasikan hal-hal yang berkaitan dengan materi yang akan dipelajari. Teksteks tersebutlah yang akan mampu menjadi peluang besar yang dapat digunakan oleh pendidik khususnya guru untuk mengembangkan bahan ajar.

Bahan ajar yang digunakan dalam pembelajaran menulis teks eksposisi jumlahnya sangat terbatas. Menulis teks eksposisi merupakan keterampilan yang mempunyai peranan yang sangat penting dalam kehidupan manusia untuk menyampaikan informasi sejelas-jelasnya, menambah wawasan dan pengetahuan.Bahan ajar adalah salah satu alternatif pemerintah dalam usahanya untuk mencapai tujuan pendidikan. Inovasi yang dapat dilakukan adalah dengan menciptakan bahan suatu bahan ajar yang lebih baik, sehingga wawasan peserta didik dalam pembelajaran teks eksposisi semakin banyak dan berkembang. Menulis bahan ajar berarti mengajarkan sesuatu mata pelajaran melalui tulisan. Oleh karena itu, bahasa yang digunakan pun bukan bahasa buku tejs yang bersifat sangat formal, melainkan bahasa yang setengah formal dan lisan.

Mengingat bahwa pengembangan bahan ajar merupakan suatu kegiatan yang penting dilakukan sebagai penunjang dalam pembelajaran siswa, maka pengembangan bahan ajar perlu ditingkatkan lagi. seperti dikatakan di atas, bahwa tujuan yang harus dicapai dari proses pembelajaran memahami teks eksposisi ini adalah agar siswa dapat memahami struktur dan kaidah penulisan teks eksposisi hingga pada akhirnya siswa bisa menuangkan ide dan gagasannya secara sitematis ke dalam sebuah tulisan untuk mancapai tujuan tersebut guru harus mampu menghadirkan bebagai macam cara, baik dalam pemilihan metode, media maupun bahan ajar. Teks eksposisi merupakan fokus dari penelitian ini dimana teks eksposisi merupakan tulisan yang memberikan informasi mengenai mengapa dan bagaimana serta menjelaskan sebuah proses atau konsep mengenai suatu yang terjadi. Tujuan teks eksposisi memberikan informasi, menjelaskan dan menjawab pertanyaan mengapa, apa, kapan, dan bagaimana. Teks eksposisi bersifat memberikan pemaparan yang berisi informasi secara objektif dengan jelas sehingga pembaca atau pendengar mendapat kejelasan tentang topik bahasan dalam tulisan atau pembicaraan.

Umumnya pada saat pembelajaran teks eksposisi, guru dan siswa menggunakan buku teks eksposisi, guru dan siswa menggunakan buku teks yang diberikan pemerintah sebagai sumber pembelajaran. Buku teks memuat seluruh kompetensi dasar yang harus dikuasai oleh siswa termasuk didalamnya tentang memproduksi teks eksposisi. Akan tetapi buku teks tersebut tidak mencukupi kebutuhan siswa dalam pembelajaran teks eksposisi. Menurut siswa pemaparan materi atau pembahasan yang terdapat dibuku ajar yang di berikan pemerintah sangat terbatas.

Berkaitan dengan teks ekposisi, penelitian-penelitian terdahulu menunjukkan bahwa selama ini menulis teks eksposisi tidaklah mudah bagi peserta didik. Oleh karena itu, penelitian yang dilakukan menawarkan model pembelajaran. Seperti halnya penelitian 
FON : Jurnal Pendidikan Bahasa dan Sastra Indonesia

Volume 15 Nomor 2 Tahun 2019

yang telah dilakukan oleh Nanang Maulana dengan judul tesis "Penggunaan Metode Pembelajaran Berbasis Masalah (Problem Based Learning) untuk Meningkatkan Kemampuan Menulis Eksposisi dan Berpikir Kritis di SMAN 19 Bandung Tahun 2014”. Dari hasil penelitian itu, simpulan yang diperoleh bahwa peningkatan berpikir kritis dan menulis eksposisi dengan menggunakan metode berbasis masalah lebih meningkat secara signifikan daripada siswa yang mengikuti pembelajaran biasa. Sementara itu, Elis Nurfatia Agung juga pernah meneliti kemampuan menulis karangan eksposisi dengan judul "Pembelajaran Menulis karangan Eksposisi Analisis Proses Berbasis Kecakapan Vokasional dengan Metode Kolaborasi (Eksperimen pada Siswa Kelas XI Akuntasi SMK Mutiara Baru Kota Bekasi Tahun Ajaran 2013/2014). Penelitian itu juga memberikan simpulan bahwa metode kolaborasi dalam pembelajaran menulis karangan eksposisi analisis proses berbasis kecakapan vokasional efektif.

Berdasarkan latar belakang di atas, tujuan penelitian ini adalah untuk identifikasi proses pengembangan bahan ajar teks eksposisi, siswa kelas X SMA Negeri 14 Medan, dari segi efektifitas dan kelayakan hasil validasi

\section{METODE}

Metode yang digunakan dalam penelitian ini adalah metode penelitian pengembangan (Research \& Development). Metode penelitian dan pengembangan adalah metode penelitian yang digunakan untuk menghasilkan produk tertentu dan menguji keefektifannya. Menurut Borg dan Gall dalam Sugiyono (2015, hlm. 297) yang dimaksud dengan model penelitian dan pengembangan adalah "a process used develop and validate educational product". Jadi, penelitian pengembangan sebagai usaha untuk mengembangkan dan memvalidasi produk-produk yang digunakan dalam proses pembelajaran.

Prosedur penelitian dan pengembangan Research \& Development $(R$ and $D)$ berdasarkan Sugiyono (2015) adalah sebagai berikut: potensi dan masalah, mengumpulkan informasi, desain produk, validasi produk, revisi produk, ujicoba produk awal, revisi produk awal, ujicoba produk akhir, revisi produk akhir, dan produk akhir.

Subjek penelitian ini adalah siswa kelas X SMA Negeri 14 Medan Tahun Pembelajaran 2018/2019. Objek penelitian ini adalah teks eksposisi yang diimplementasikan pada siswa kelas $\mathrm{X}$ SMA Negeri 14 Medan Tahun Pembelajaran 2018/2019.

Instrumen penelitian yang digunakan untuk menilai kelayakan bahan ajar dalam pembelajaran menulis teks eksposisi adalah tes, angket dan lembar validasi.

Teknik pengumpulan data melalui tes ini digunakan untuk mengukur keterampilan menulis siswa.Pada penelitian ini untuk menjaring data yang dibutuhkan, penulis menggunakan tes, dimana siswa disuruh untuk menulis teks eksposisi. Adapun penjelasan instrumen angket yang digunakan dalam penelitian ini yaitu angket tanggapan peserta didik tentang menulis.

Angket ini berisi pernyataan yang berguna untuk mendapatkan informasi mengenai persepsi peserta didik tentang menulis. Angket ini dibagikan kepada peserta didik kelas X SMA Negeri 14 Medan Tahun Pembelajaran 2018-2019.

Penelitian ini menggunakan lembar validasi tentang kelayakan bahan ajar dalam pembelajaran menulis teks eksposisi yang telah disusun. Lembar validasi ini merupakan pedoman bagi dosen ahli yang akan memberikan 
masukan dan penilaian berdasarkan empat aspek yang meliputi :aspek kelayakan isi, aspek kelayakan kebahasaan, aspek kelayakan penyajian materi dan aspek kelayakan kegrafisan.

Teknik pengumpulan data dalam penelitian ini menggunakan teknik, tes,angket dan lembar validasi.

\section{HASIL DAN PEMBAHASAN}

Data yang diperolehdalam penelitian ini menggunakan teknik tes teks eksposisi, dan angket. Teks yang digunakan dalam penelitian ini adalah teks eksposisi. Dimana peserta didik disuruh untuk menulis teks eksposisi sesuai dengan kriteria yang ditentukan. Terdapat sejumlah 31 responden yang ikut dalam tes menulis teks eksposisi ini. Pengambilan data tes menulis teks eksposisi berlangsung dengan baik dan lancar.

Selanjutnya pengambilan data angket dilaksanakan di ruang kelas $\mathrm{X}$ SMA Negeri 14 Medan Tahun Pembelajaran 2018-2019 yang berjumlah 31 peserta didik yang dijadikan subjek dalam penelitian. Pada hari pengambilan angket yang hadir 31 peserta didik, sehingga terdapat 31 peserta didik yang dijadikan subjek dalam penelitian ini. Proses pengambilan data angket berlangsung selama 30 menit.

Proses pelaksanaan pengembangan bahan ajar teks ekposisi ini dilakukan dengan beberapa tahap. Tahap pertama yaitu dengan melakukan survei lapangan dalam melakukan analisis masalah dan analisis kebutuhan di SMA Negeri 14 Medan yang merupakan latar belakang masalah penelitian pengembangan dengan menebar angket..Tahap ini dilakukan untuk memahami ide atau gagasan agar produk yang dikembangkan sesuai dengan kebutuhan. Studi pendahuluan ini dilakukan dengan cara membagikan angket kepada 2 orang yaitu 1 validator dari tim ahli dan 1 guru bahasa Indonesia dan 31 peserta didik di SMA Negeri 14 Medan tersebut dengan terlebih dahulu menguraikan definisi dari bahan ajar pada angket agar memiliki gambaran tentang pertanyaan dalam angket yang disampaikan. Hasil penelusuran dari angket ditemukan $100 \%$ dari guru dan siswa menyatakan membutuhkan bahan ajar pada materi teks eksposisi dalam proses pembelajaran agar berjalan lebih efektif dan agar dapat dijadikan oleh peserta didik sebagai sarana pembelajaran secara individual.

Kemudian berdasarkan hasil analisis terhadap kebutuhan bahan ajar, di dapati bahwa guru hanya menggunakan buku teks Kemdikbud dalam pembelajaran teks eksposisi di sekolah dan tidak memiliki bahan ajar lain selain buku teks tersebut, tentunya hal ini sangat riskan karena peserta didik kurang mendapatkan pengetahuan yang lebih mendalam dan peserta didik tidak sepenuhnya dapat mengeksplorasi kemampuannya dalam kegiatan menulis teks eksposisi. Sebanyak $40 \%$ guru dari yang di survei, belum mengenal bahan ajar berupa modul pembelajaran. Hal ini tentunya semakin memperkuat data bahwa tidak ada bahan ajar pendamping dalam pelajaran bahasa Indonesia.di sekolah. Lalu, guru juga membutuhkan bahan ajar yang dapat meningkatkan nilai peserta didik dalam menulis teks eksposisi dan setuju terhadap pengembangan bahan ajar teks eksposisi karena kurangnya kemampuan peserta didik dalam menulis teks eksposisi menggunakan buku teks yang selama ini digunakan.

Hasil analisis kebutuhan bahan ajar siswa menunjukkan bahwa siswa hanya menggunakan satu buku sebagai sumber belajar yaitu buku teks Kemdikbud. Semua siswa menyatakan tidak menggunakan bahan ajar berupa modul pembelajaran. Sebanyak $60 \%$ siswa menyatakan tertarik dalam pembelajaran teks eksposisi dan data juga menunjukkan 
FON : Jurnal Pendidikan Bahasa dan Sastra Indonesia

Volume 15 Nomor 2 Tahun 2019

bahwa dalam proses pembelajarannya

konteks dan sebanyak $90 \%$ responden mereka mengalami kesulitan dalam menulis teks eksposisi dan didapati data sebanyak $60 \%$ siswa menyatakan mengalami kesulitan dalam menulis teks eksposisi. Hal ini tentunya sangat membutuhkan perhatian khusus dalam pembuatan bahan ajar berbentuk modul yang layak digunakan bagi siswa. Kemudian sebanyak $60 \%$ siswa menyatakan bahwa bahan ajar yang selama ini digunakan belum sesuai dengan

meyatakan setuju tentang rencana pengembangan bahan ajar teks eksposisi sebagai solusi dalam masalah yang mereka hadapi.

Berdasarkan beberapa hasil analisis kebutuhan di atas, maka dapat disimpulkan bahwa pengembangan bahan ajar sangat dibutuhkan oleh guru maupun siswa yang sangat diharapkan mampu untuk meningkatkan nilai dan kualitas pembelajaran menulis teks eksposisi.

Tabel 1

Data Analisis Kebutuhan

\begin{tabular}{|c|l|l|c|c|c|}
\hline No & \multicolumn{1}{|c|}{ Pertanyaan } & $\begin{array}{c}\text { Jawaban } \\
(\text { Ya/Tidak })\end{array}$ & $\begin{array}{c}\text { Gur } \\
\mathrm{u}\end{array}$ & Siswa & Jumlah \\
\hline \multirow{2}{*}{1} & Mengenal Bahan Ajar berupa modul & Ya & 1 & 2 & 3 \\
& & Tidak & 0 & 31 & 31 \\
\hline \multirow{2}{*}{2} & Menggunakan bahan ajar berupa modul & Ya & 0 & 0 & 0 \\
& & Tidak & 1 & 31 & 31 \\
\hline \multirow{2}{*}{3} & Memerlukan bahan ajar teks eksposisi & Ya & 1 & 31 & 31 \\
& berupa modul dalam pembelajarannya & Tidak & 0 & 0 & 0 \\
\hline
\end{tabular}

Berdasarkan tabel di atas mengenai analisis kebutuhan oleh guru dan siswa diperoleh kesimpulan sebagai berikut: (1) Sebagian besar siswa menyatakan belum mengenal bahan ajar berupa modul, sedangkan semua guru dan sebagian kecil siswa menyatakan telah mengenal bahan ajar berupa modul. (2) Guru dan siswa tidak menggunakan bahan ajar berupa modul dalam proses pembelajarannya. (3) Semua guru dan siswa menyatakan memerlukan bahan ajar teks eksposisi berupa modul dalam proses pembelajaran.

Berdasarkan analisis kebutuhan tersebut disimpulkan bahwa pengembangan bahan ajar sangat dibutuhkan oleh guru dan siswa dalam proses pembelajaran untuk meningkatkan kualitas pembelajaran. Selanjutnya, peneliti melakukan perencanaan bahan ajar berupa modul teks eksposisi. Kemudian, bahan ajar yang telah dikembangkan di validasi oleh ahli materi dan ahli desain pembelajaran. Setelah di validkan, produk diujicobakan pada perorangan, kelompok kecil, dan kelompok lapangan terbatas, selanjutnya dilakukan revisi. Dengan demikian bahan ajar yang diperoleh telah valid.

Penyusunan bahan ajar yang dilakukan berdasarkan analisis masalah yang telah didapat sebelumnya yaitu dengan mengembangkan bahan ajar teks eksposisi. Bahan ajar yang telah disusun lalu divalidasikan oleh ahli materi pembelajaran. Setelah dinyatakan valid, maka produk ini akan diuji cobakan pada kelompok perorangan, kelompok kecil, dan kelompok terbatas. Dengan demikian bahan ajar yang dikembangkan telah baik dengan memenuhi kriteria skor penilaian yang telah ditetapkan.

Adapun perancangan bahan ajar yang dihasilkan dapat dijabarkan sebagai berikut : sampul (cover), materi teks eksposisi, contoh teks eksposisi, uji 
FON : Jurnal Pendidikan Bahasa dan Sastra Indonesia

Volume 15 Nomor 2 Tahun 2019

kompetensi atau aktivitas-aktivitas dalam bentuk soal dan latihan.

Validasi oleh ahli materi dimaksudkan untuk mengetahui pendapat ahli materi tentang isi, kelayakan penyajian, bahasa dan kegrafikan terhadap bahan ajar teks eksposisi. Validasi ini dilakukan oleh dosen bahasa di Universitas Muslim Nusantara AlWasliyah Medan dan guru mata pelajaran Bahasa Indonesia di SMA Negeri 14 Medan. Validasi ini dilakukan untuk memperoleh bahan ajar yang bermutu untuk meningkatkan pembelajaran bahasa Indonesia di jenjang SMA berjumlah 31 orang peserta didik yang terutama pada materi teks eksposisi.

Pada tahap ini dilakukan uji coba terhadap produk yang dihasilkan berupa bahan ajar berbentuk modul pembelajaran. Uji coba ini juga melalui tahapan lagi yaitu uji coba perorangan (3 siswa), uji coba kelompok kecil (9 siswa), dan uji coba lapangan terbatas (31 siswa).

Proses pengembangan bahan ajar teks eksposisi berfokus pada hasil tes menulis teks eksposisi. Berdasarkan data yang diperoleh penelitian tersebut kemudian akan dikembangkan bahan ajar yang sesuai dengan kebutuhan dan kondisi siswa. Pengembangan bahan ajar teks eksposisi yang dilakukan oleh peneliti diharapkan mampu meningkatkan keterampilan siswa dalam menulis teks eksposisi.

Dilihat dari hasil tes menulis teks eksposisi sebelum dilakukan pengembangan bahan ajar teks eksposisi yaitu sebesar 61,29 yang berada pada kategori cukup. Setelah dilakukan pengembangan bahan ajar menulis teks eksposisi yaitu sebesar 87,74 yang berada pada kategori sangat baik. Dari hasil tersebut, terlihat bahwa pengembangan bahan ajar menulis teks eksposisi efektif dalam meningkatkan keterampilan menulis teks eksposisi oleh peserta didik kelas X SMA Negeri 14 Medan Tahun Pembelajaran 2018-2019.

Dari hasil tes menulis teks eksposisi peserta didik, yang diperoleh bahwa nilai terendah yang diperoleh siswa adalah 45 dan nilai tertinggi yang diperoleh peserta didik adalah 70 dengan nilai rata-rata secara keseluruhan sebesar 1900.Apabila nilai rata-rata tersebut dikonsultasikan dengan kriteria penilaian, maka nilai rata-rata 61,29 berada pada kriteria cukup. Dengan demikian, disimpulkan bahwa menulis teks eksposisi peserta didik kelas X SMA Negeri 14 Medan berada pada kategori cukup.

Dari hasil tes menulis teks eksposisi peserta didik yang diperoleh, diketahui bahwa nilai terendah adalah 80 dan nilai tertinggi yang diperoleh peserta didik adalah 95 dengan nilai rata-rata secara keseluruhan sebesar 2720 Apabila nilai rata-rata tersebut dikonsultasikan dengan kriteria penilaian, maka nilai ratarata 87,74 berada pada kriteria baik. Dengan demikian, disimpulkan bahwa menulis teks eksposisi peserta didik kelas X SMA Negeri 14 Medan setelah dilakukan pengembangan bahan ajar teks eksposisi berada pada kriteria baik.

Penilaian oleh ahli dari aspek kelayakan isi memperoleh rata-rata nilai 59 dengan persentase $84,28 \%$ dengan kriteria "sangat baik". Penilaian oleh ahli dari aspek kelayakan penyajian dengan rata-rata nilai 68 dengan persentase $85 \%$ dan kriteria "sangat baik". Penilaian oleh ahli dari aspek kebahasaan dengan ratarata nilai 69 dengan persentase $86,25 \%$ termasuk dalam kategori "sangat baik". Penilaian ahli materi pengembangan bahan ajar teks eksposisi dari aspek kelayakan kegrafikan memperoleh nilai rata-rata 91 dengan persentasi $91 \%$ dengan kategori "sangat baik". Berdasarkan hasil penelitian sebelum dilakukan pengembangan bahan ajar menulis teks ekpsosisi, menunjukkan bahwa hasil tes keterampilan menulis teks 
FON : Jurnal Pendidikan Bahasa dan Sastra Indonesia

Volume 15 Nomor 2 Tahun 2019

eksposisi peserta didik berada pada kategori baik.

\section{KESIMPULAN}

Proses pengembangan bahan ajar teks ekpsosisi siswa kelas X SMA Negeri 14 Medan Tahun Pembelajaran 2018-2019 yaitu studi pendahuluan dengan menemukan informasi yang didapat melalui angket analisis kebutuhan siswa dalam studi lapangan di sekolah. Kemudian melakukan tahap penyusunan produk awal teks eksposisi dalam kegiatan pembelajarannya untuk nantinya dilakukan validasi terhadap ahli atas aspek kelayakan isi/materi, kelayakan penyajian, kelayakan bahasa dan kelayakan kegrafikan yang dilakukan oleh 1 orang validator dan 1 orang guru mata pelajaran bahasa Indonesia dan setelah melewati tahap validatsi akhirnya produk dalam bentuk bahan ajar modul ini melakukan tahap ujicoba produk kepada peserta didik yang berjumlah 31 orang di SMA Negeri 14 Medan.

Efektivitas pengembangan bahan ajar teks eksposisi berdasarkan hasil penghitungan yang telah peneliti lakukan, menunjukkan bahwa nilai rata-rata keterampilan menulis teks eksposisi peserta didik sebelum dilakukan pengembangan bahan ajar menulis teks eksposisi yaitu sebesar 61,29. Dengan demikian rata-rata tingkat keterampilan menulis teks eksposisi oleh paesrta didik kelas X SMA Negeri 14 Medan Tahun Pembelajaran 2018-2019 sebelum dilakukan pengembangan bahan ajar menulis teks eksposisi dapat dikatakan cukup.

Selanjutnya, setelah dilakukan pengembangan bahan ajar menulis teks eksposisimenunjukkan bahwa hasil nilai rata-rata keterampilan menulis teks eksposisi yang dimiliki peserta didik yaitu sebesar 87,74. Dengan demikian, rata-rata tingkat keterampilan menulis teks eksposisi oleh peserta didik kelas X SMA

Negeri 14 Medan Tahun Pembelajaran 2018-2019 setelah pengembangan dapat dikatakan baik. Dari hasil tersebut, terlihat bahwa pengembangan bahan ajar menulis teks eksposisi efektif dalam meningkatkan keterampilan menulis teks eksposisi, dimana sebelum proses pengembangan bahan ajar berada pada kategori cukup dan kemudian meningkat menjadi baik.

Hasil validasi pengamatan pengembangan bahan ajar teks eksposisi peserta didik kelas X SMA Negeri 14 Medan Tahun Pembelajaran 2018-2019 menunjukkan bahwa aspek kelayakan materi diperoleh sekor rata-rata validasi $84,28 \%$ dengan kategori baik. Kemudian pada aspek kelayakan penyajian materi diperoleh skor rata-rata validasi sebesar $86,25 \%$ dengan kategori baik dan padam aspek kelayakan bahasa diketahui sekor rata-rata validasi adalah $86,25 \%$ dengan kategori baik, serta pada aspek kelayakan kegrafisan diketahui sekor rata-rata validasi $91 \%$ dengan kategori baik. Dengan demikian, dapat disimpulkan bahwa pengembangan bahan ajar teks eksposisi layak digunakan peserta didik kelas X SMA Negeri 14 Medan Tahun Pembelajaran 2018-2019.

Guru harus selalu mengikuti perkembangan informasi khususnya mengenani penggunaan pendekatan, metode, model, dan strategi pembelajaran yang terbaru/inovatif, sehingga guru dapat menerapkannya di kelas dan diharapkan mampu untuk mengadakan pembe;lajaran yang interaktif yang mampu untuk memotivasi kreativitas dan keaktifan peserta didik.

Peserta didik harus berani aktif serta mampu untuk memperlihatkan keaktifannya dalam kegiatan pembelajaran khususnya dalam kegiatan pembelajaran menulis teks eksposisi.

Hasil penelitian ini dapat dijadikan sebagai acuan untuk penelitian selanjutnya, sehingga pengembangan 
FON : Jurnal Pendidikan Bahasa dan Sastra Indonesia

Volume 15 Nomor 2 Tahun 2019

bahan ajar teks eksposisi ini tidak berhenti, akan tetapi terus berkembang untuk meningkatkan kualitas pengembangan bahan ajar ke pembelajaran yang lebih baik lagi.

\section{DAFTAR PUSTAKA}

Hamdani. (2011). Strategi Belajar Mengajar. Bandung: Pustaka Setia.

Iskandarwassid dan Dadang Sunendar. (2009). Strategi Pembelajaran Bahasa. Bandung: Remaja Rosdakarya.

Jauhari, H. (2013). Terampil Mengarang. Bandung: Nuansa Cendekia.

Kemendikbud. (2013). Peraturan Menteri Pendidikan dan Kebudayaan, Nomor 81A, Tahun 2013, tentang Implementasi Kurikulum Pedoman Umum Pembelajaran. Jakarta: Kemendikbud.

Kosasih, E. (2012). Bahasa Indonesia: Buku Guru. Jakarta. Kementerian Pendidikan dan Kebudayaan.
Opara, J.A. \& Oguzor, N.S. (2011). Inquiry Instructional Method and the School Science Curriculum. Current Research Journal of Social Sciences, 3(3), 188-198.

Sugiyono. (2015). Metode Penelitian Pendidikan (Pendekatan Kuantitatif, Kualitatif dan $R \& D)$, Bandung: Alfabeta.

Waluyo, Herman. (2014). Apresiasi Puisi. Jakarta: Gramedia Pustaka Umum.

Wardhana, Yana. (2010). Teori Belajar dan Mengajar. Bandung: Pribumi Mekar.

Wulandari, Novita. (2014). Keefektifan Pembelajaran CIRC dengan Pendekatan Open-Ended Terhadap Kemampuan Berpikir Kreatif Siswa Kelas-VIII Materi KubisBalok. Unnes Journal of Mathematics Education, 3(3), 2014.

Zainurrahman. (2013). Menulis: Dari Teori Hingga Praktik (Penawar Racun Plagiarisme). Bandung: Alfabeta. 